\title{
Public Regulated Models for Business
}

\author{
Submitted 11/05/20, 1st revision 09/06/20, 2nd revision 17/07/20, accepted 30/07/20
}

\section{Zyryanov Sergey M. ${ }^{1}$, Kalmykova Anastasia V. ${ }^{2}$}

\section{Abstract:}

Purpose: The purpose of this article is to clarify the "regulation" term meaning, to distinct between regulation and market, economic means of influence on social relations as well as the systematization of regulatory policy models implemented according to the legislation of the Russian Federation in comparison with models in other states, for example, the USA, the $U K$ and other countries.

Design/Methodology/Approach: The authors use methods of comparative law, the interpretation of legal conceptions and normative legal acts. The authors come from the prerequisite that the common objectives of regulating policy in different countries are connected with the similarity of regulatory policy models. However, different social and economic conditions and, that is no less important, regulatory traditions determine differences in integrative national regulatory policies in different countries.

Findings: The authors suggest to consider regulation as a set of administrative and legal methods of influence on public relations connected with goods' production, performance of works and service provision, this will exclude from the subject of different legal research methods. At the same time, due to legal systems peculiarities of the former USSR the administrative responsibility is absent in most countries as an independent type of legal responsibility should be included in the regulation. In accordance with significant feature of these countries' regulatory policies regulating prospective forms that are not provided for by law may be implemented in law enforcement practice.

Practical Implications: The results can be implemented in the legislation of the Russian Federation and other countries in order to improve the efficiency and effectiveness of the executive authorities' regulatory activity.

Originality/Value: The main contribution of this article is a comparative legal analysis of regulatory policy models in Russia, the United States, Great Britain and European countries, and the conclusions developed the modern administrative and legal theory of regulation.

Keywords: Regulation, regulatory policy, executive authorities, normative legal acts, control, administrative responsibility.

JEL Code: K23, K42, L9.

Paper type: Research article.

\footnotetext{
${ }^{I}$ The Institute of Legislation and Comparative Law under the Government of the Russian Federation, Plekhanov Russian University of Economics, ORCID 0000-0003-2592-9695 zyryanov.s@gmail.com;

${ }^{2}$ The Institute of Legislation and Comparative Law under the Government of the Russian Federation; NRU «High School of Economics», efimova_anastasi@mail.ru;
} 


\section{Introduction}

The modern state faces complex and often contradictory political, social, and economic challenges. In particular, tasks aimed at countering threats and ensuring security of citizens and a state require restrictions, that as a rule, lead to the economic development slowdown. At the same time, creating conditions for the accelerated economic development may also pose a threat to the social rights of citizens. The external and internal socio-economic and political environment is changing quite rapidly, and these changes can be extremely abrupt as in the first half of 2020 in connection with the Covid-19 pandemic. It was necessary for governments to take emergency measures, often not provided for by law.

The experience accumulated during the entire history of the human's society development shows that the state regulation is possible, its primary subject is the executive power, and also in some countries independent agencies operating in the administrative and legal field, private regulation and their combination in different proportions. According to general opinion market regulation based on free will have people and companies in priority. From this point of view, the state interference should take place in exceptional cases when the market is not able to ensure human rights protection, fair distribution of public goods, or security (market failure). Supporters of active state interference in regulating economic relations believe that the market economy cannot "cure" itself without any help. According to public interest proponents the balance should be towards the state regulation as one of these two main regulation types. Such an imbalance causes an increase in administrative costs both for the state and business, hinders the economic development and threatens the public good.

Even a superficial retrospective analysis shows that different countries facing this phenomenon are forced to change regulatory policies and reform legal and institutional regulatory systems, expand the range of regulatory methods, and conduct the deregulation. The purpose of this article is to develop ideas about the regulation and regulatory policy, the systematization of well-known traditional and new models of regulatory policy in a modern democratic state. The purpose of the article determines the following tasks:

- clarifying the regulation concept;

- the analysis of market, economic and social (including legal) ways of influencing public relations;

- defining regulatory policy limits;

- systematizing the regulatory policy models;

- the comparative analysis of legal and institutional regulatory reforms;

- characteristics of the relationship between the regulatory policy legal formalization and its actual implementation in the law enforcement practice of regulatory authorities. 
The research object is regulatory policy in a modern democratic state. The research subject is the legal and institutional framework for the development and the implementation of regulatory policy.

\section{Materials and Methods of Research}

Before the regulation theory in Russian administrative law has not been developed as an independent phenomenon and included in the public administration concept, studied by Lunev (1974), Pavlovsky (1985), Atamanchuk (2005), Popov, Migachev, and Tikhomirov (2012).

This research is based on theoretical works by experts in the field of regulation, investigating its content, forms and methods of implementing regulatory policy, such as Ogus (2004), Coglianese and Lazer (2011), Adler (2009), Scholz (1997), Ayres and Braithawite (1992), Zyryanov (2010), and Nozdrachev et al. (2017).

The literature review has shown that, despite many papers on the regulation theory, there is still a lot of unresolved questions. First of all, in defining the regulatory sphere limits. There are several approaches: (1) relationships connected with business. In this case, relations formed in various types of social and economic activity of citizens and not connected with entrepreneurial activity are not regulated; (2) any relationship in which state bodies and state institutions participate.

In this case, the question about the participation of public associations or public-state organizations with separate public functions remains urgent. The second question is about defining activity that falls within the scope of state regulation since relations connected with the implementation of some types of activity not always need state regulation, and in some cases their regulation by public legal means is simply impossible or it does not ensure compliance with the requirements. The third debatable issue is the means of influence on public relations, the state has a wide range of legal means from establishing criminal law prohibitions to non-regulation in some cases.

The information and analytical basis of the study consists of reports, presentations and other information materials on the official websites of governments, government departments, regulatory agencies, integration entities such as the EEU and the EU. In addition, the authors studied and used materials describing the regulatory reforms through the deregulation, the decentralization, the simplification of administrative procedures, and the regulatory guillotine over the past decades.

The research is carried out as part of the reforming regulatory policy, licensing and supervisory activity in the Russian Federation. The methodological basis is general scientific and special methods of cognition. Regulatory policy models, methods of analysis and synthesis, formal logic, comparative law, and the law interpretation were used in this research. 


\section{Discussion and Results}

Experts do not give an exact regulation concept definition. The legislation analysis allows to define a little conditionally few regulation models: (1) the regulation based on the command and control regulation method, typical for the socialist system of law and order; (2) the regulation based on the permissive method; (3) regulation of the business community with the predominant share of self-regulation; (4) regulation based on a risk-oriented approach, it involves regulation only of those areas the violation of which entails risks to health and life of citizens, significant damage to the environment.

The methods used for regulation in these models also differ depending on: (1) the economy sphere (production and turnover of medicines, passenger or cargo transportation, weapons production, mining, electricity production, etc.); (2) the goals (labour protection, environmental protection, consumer rights protection, information protection, etc.); (3) economic, social and other conditions; (4) national law features.

The question of criteria for choosing a particular regulatory method or even a more general principle choice between industry-specific regulatory methods is unavoidable. In many cases, a free market can be a fairly effective regulator that provides significant savings in legal and organizational (and therefore financial) resources. In other cases, it is impossible to do without administrative and legal regulation. And sometimes it is necessary to use more powerful means - criminallegal regulation. To a lesser extent, the regulatory possibilities of tax, budget and financial regulation are used.

All these means together in the national law of a state should be balanced for some conditions of the economic and social development, even if in a particular country at a certain time private law, financial-budgetary or administrative-command regulation dominate, since their imbalance will lead to an economic or social crisis.

However, we are wholly agree with Adler's view, that first of all regulation is carried out by public law, but not private one. Regulation is never perfect or even effective enough. The priority task almost in all the countries is to find ways to improve the regulation effectiveness. This is the reason for the development and the implementation of various already mentioned reforms. Such large-scale reforms are rarely completed and they do not change the general regulatory model completely.

An interesting analysis of the economic deregulation reform in the United States was made by American scientists. For example, Ian Ayres and John Braithwaite note in their well-known work that attempts by Republican administrations with their strong commitment to deregulation in the first years of their activity, by the end of the second term of the Republican President, only tightened the regulatory pressure on business. Thus, in the early years of President Reagan's administration, there was a 
fairly strong deregulation in environmental protection. In 1982, the General Accounting Office found out that the environmental protection Agency's (EPA) enforcement actions under the Clean water act had fallen to 27\% from the 1977 peak. But the deregulation caused a backlash and in 1984 enforcement exceeded the level of 1977 by $30 \%$. In the next years, law enforcement accelerated, especially criminal one.

Prison sentences for Federal environmental crimes during the fiscal 1986-1989 years were more than 9 times higher than they were in 1983-1985. The transfer of civil lawsuits to the justice Department in 1986-1989 by EPA also increased by 2 times compared to 1981-1985 during the Carter's administration. The President Reagan's administration in the early years sought to deregulate control over nursing homes by replacing annual government inspections with three-year inspections (American Council on Hospital Standards).

The number of inspectors for health facilities (mainly nursing homes) was reduced from 2,400 to 1,800 in 1982. By the end of the President Reagan's second term, the number of these inspectors exceeded 4,000. Moreover, during the Reagan era, the federal cooperation policy in regulating nursing homes was drastically changed and replaced with increased enforcement. Law enforcement relating to nursing homes significantly increased during that period, and in 1987 Congress adopted a number of new strict standards.

In Russia, in 2003, a large-scale administrative reform was launched, which resulted in the reform of the entire system and the structure of executive power, and the redistribution of functions between executive bodies. The most significant characteristics of this reform were, first, the approval of certain principles of the Executive power organization, and secondly, significant reduction in the powers of Executive bodies. In particular, it was established that in the executive power system at the Federation level, managed by the government, executive bodies of three organizational types are formed. These are ministries, services and agencies. Naturally, a set of functions was defined for each type of organ. For example, the Ministry develops state policy and implements normative legal regulation in the sphere of its competence. The service performs licensing and supervisory functions, and the agency manages state property and provides services. There was an idea to completely delineate the competence of these bodies, but it was not implemented. Over time, it can be stated that many ministries perform control and supervision functions, manage state property, and provide public services.

Many services and some agencies participate in the development of public policy and in the development of normative legal acts, and sometimes they have the right to approve independently these normative legal acts, setting mandatory requirements. The reduction of the number of the Executive authorities' power also appears to be a failure from the standpoint of today. The total number of them quickly recovered and continued to grow, many times exceeding the pre-reform number. For example, 
the Russian Ministry of economy in 1995 had 29 powers, in $2000-31$, in 2003 140, in 2004 after the reform it had 67, in $2012-147$, in 2020 - more than 200 powers. Active regulatory rulemaking carried out by the legislator, the government, executive bodies and, taking into account that Russia is a Federal state, by the subjects of the Russian Federation is also connected with a large number of powers. To date, the scope of legal regulation has exceeded imaginable limits to such an extent that the regulatory authorities are not able to determine the number of mandatory requirements that they are called upon to ensure compliance with in their control and supervisory activity.

Regulatory legal acts issued 80, 50, and 30 years ago still operate, and new acts establishing similar requirements are being adopted, which creates legal uncertainty and conflicts. In this mass, there are many either redundant requirements, or requirements that are technically impossible to fulfill, or the cost of fulfilling them is so high that it makes no sense to continue operating. This situation negatively affects the economic activity and investment attractiveness of Russia, which makes it necessary to look for new mechanisms for regulating economic relations. It is clear that such a status quo suits neither business nor the government, which over the past decade and a half has been searching for management mechanisms of different sectoral nature.

These include territorial preferential regimes of several types (special (free) economic zones, industrial production, technical and innovation, tourist and recreational types, the Vladivostok free port), the adoption and the implementation of state and state investment programs (the development of agriculture, shipbuilding and equipment for offshore fields, electronic and radio-electronic industry, etc.), the national projects implementation such as "Safe and high-quality roads", "Labour productivity and employment support", "Ecology", "Housing and urban environment", "Digital economy of the Russian Federation", "Small business and support for individual entrepreneurial initiative", etc. These measures are based mainly on the provision of tax benefits, budget subsidies, reducing rental rates for residents and the control intensity by regulators. Despite the fact that the above examples present tax and fiscal mechanisms, however, they operate only within the framework of special administrative and legal regimes.

Unfortunately, all these efforts do not yield quick tangible results and the main method of regulation still is state regulation by administrative and legal means. At the same time, frustration arises due to soft means of regulation while maintaining strict administrative pressure.

In order to alleviate this pressure, a large-scale regulatory reform has been launched in Russia since 2019, the implementation of which provides for a regulatory guillotine and the new legal regulatory mechanism formation that covers all the main stages of the regulatory process: (1) rulemaking aimed at the mandatory requirements establishment, legal monitoring and sometimes review of previously 
approved mandatory requirements; (2) optimizing state's licensing activity; (3) improving state control (supervision) over compliance with mandatory requirements with an emphasis on the cooperation and the prevention of offenses; (4) optimizing administrative responsibility of economic entities (legal entities and individual entrepreneurs) for the mandatory requirements violation. Such a comprehensive solution gives hope that administrative barriers will be lowered at last, and in a more liberal environment we will see the economic development acceleration.

\section{Conclusion}

All the countries face the problem of choosing a regulatory policy. In recent years, this problem has become most acute for Russia. The impact on public relations is considered to be carried out by various means, but we came to the conclusion that the normal functioning of these means is impossible without administrative and legal regulation. The regulatory policy models implemented by administrative measures are described in sufficient detail in the legal literature, they are fixed in legislation.

However, it is not possible in all the cases to implement them in law-enforcement activity, characterized by some inertia, due, first of all, psychology of regulating authorities employees, as well as traditional thinking of the whole society, including the business community, managers and employees of regulated authorities. The failure of administrative reforms carried out in Russia over the past two decades is largely due to this.

In this regard, the regulatory guillotine reform launched in 2019, which should result in a new regulatory mechanism covering all the stages of the regulatory process from rulemaking to the administrative enforcement to evaders, gives hope for success.

\section{References:}

Adler, M.D. 2009. Regulatory Theory. Faculty Scholarship Paper 301.

Administrative legal regimes in state management of the Russian Federation: theory and actual practice: Monograph / The Institute of Legislation and Comparative Law under the Government of the Russian Federation: Law firm Contract, 528 p.

Atamanchuk, G.V. 2005. Administrative reform in Russia. Scientific and Practical Manual. Teoriya Gosudarstvenny Control, Course of lectures.

Ayres, I., Braithwaite J. 1992. Bulatov Economics: The textbook / edited 2nd ed.

Beck, B. 1992. Responsive Regulation. Oxford university press.

Boltanova, E.S., Zdorovtseva, S.A., Zolotova, A.O....chief ed. A.F. Nozdrachev. 2016.

Coglianese, C., Lazer, D. 2011. Management-Based Regulation: Prescribing Private Management to achieve Public Goals. Law \& Society Review, 37(4), 691-730.

Published by: Blackwell Publishing on behalf of the Law and Society.

Lazarev, B.M. 1972. Competence of the authorities, 280 p.

Legal regulation of state control. 2012. Monograph / Executive editors: Doctor of Juridical Science, professor, Honoured Science Worker of Russian Federation A.F. Nozdrachev, 603 p. 
Lunev, A.E. 1974. Theoretical problems of public administration. Moscow.

Nozdrachev, A.F., Zyryanov, S.M., Kalmykova, A.V. 2017. Reform of State Control (Supervision) in the Russian Federation. Russian law journal, 9, 34-46. DOI: 10.12737/article_599d74421f88b5.06552344.

Ogus, A. 2004. Regulation form and economic theory. Oxford-Portland Oregon, $382 \mathrm{p}$.

Pavlovsky, R.S. 1985. Administrative law and public administration in the USSR. The text of the lectures. Kharkiv.

Popov, L.L., Migacheva, E.V., Tikhomirov, S.V. 2012. State management in Russia and foreign countries: administrative and legal aspects. Edited by L.L. Popov.

Rossinsky, B.V. 2020. Administrative and legal aspects of government in Russia. Systemic approaches, $168 \mathrm{p}$.

Scholz, J.T. 1997. Enforcement policy and corporate misconduct: the changing perspective of deterrence theory. Law and Contemporary Problems, 60(3), 253-268.

Zyryanov, S.M. 2010. Administrative supervision. Monograph, 206 p.

Zyryanov, S.M., Kalmykova A.V. 2019. Approaches to assessing the effectiveness of state control bodies (surveillance) to prevent violations of mandatory requirements. Public administration issues, 3, 31-66. 